\title{
FRONTEIRAS ESPIRITUAIS E FRONTEIRAS NACIONAIS: O COMBATE ÀS SEITAS NA FRANÇA
}

Patricia Birman

Como explicar, indaga o jornalista Alain Woodrow, que jovens franceses bem formados, estudantes e/ou profissionais de nível superior, subitamente se transformem em membros da seita dirigida pelo reverendo Moon? A perplexidade que o jornalista exprimiu em 1975, em um artigo do Le Monde, decorria de uma evidência que ele quis partilhar com seus leitores: como, em suma, tamanha distância social, moral e subjetiva pôde ser ultrapassada por estes jovens que tudo abandonaram para entrar em uma seita coreana, estranha a seus valores, em confronto evidente com a formação intelectual que receberam e em contradição com o estatuto social de que dispunham?

Existe, indiscutivelmente, uma discordância entre, de um lado, a rapidez da conversão e o fanatismo dos adeptos e, de outro, a inconsistência do pensamento de Moon sob todos os pontos de vista (doutrinal, filosófico, lógica pura) $[\ldots]$ Os fatos nos conduzem a afirmar, portanto, que os jovens sofrem um condicionamento psicológico "tipo lavagem cerebral" (bem codificado desde a Segunda Guerra Mundial) que os torna insensíveis à toda crítica e inaptos a qualquer auto-crítica; tratando-se, freqüentemente, de estudantes ou de quadros de nível superior, seria "falso" ver aí uma simples ingenuidade ou inexperiência (Woodrow apud Birman 2000a:28).

Alain Woodrow descreveu para um público em escala nacional a perplexidade que este fenômeno recente, o crescimento de seitas vindas, na sua maioria, do exterior, estava provocando em certas famílias da região da Bretanha que, organizadas em uma pequena associação, a Association pour la Défense de la Famille et de l'Individu (ADFI), buscaram o seu apoio como jornalista. Ao longo de quase três décadas, esse perigo que, pela primeira vez, era enunciado nas páginas do Le Monde foi objeto de debates e controvérsias no espaço público francês. Durante esse período, 
cresceu em tamanho e em importância esta primeira associação, e outras foram fundadas com o mesmo objetivo de combate às seitas.

Naquele momento, o autor destacava a dimensão paradoxal que aparentemente encerrava a conversão de jovens abastados a uma seita fanática, de origem coreana. As habilidades intelectuais e morais de que os adeptos da seita eram portadores seriam francamente antagônicas com a opção existencial que fizeram, e mesmo inteiramente incompreensível, considerando-se suas origens sociais e o domínio pleno que teriam de suas faculdades mentais. Rompiam, por meio dessa estranha conversão, com os padrões de normalidade vigentes e, em conseqüência, com os critérios de avaliação de seus comportamentos.

Estas conversões pareciam desfazer, aos olhos desses pais, a continuidade histórica e geracional de suas existências. Teria partido com os filhos a convicção que possuíam quanto à capacidade de lhes garantir uma boa transmissão de seus valores e estilos de vida? Ou melhor, teriam perdido os meios de defendê-los dos novos flagelos sociais diante dos quais o Estado se mostrava inoperante?

Assim, construiu-se a hipótese de uma lavagem cerebral como modo de recrutamento promovido pelas seitas no final dos anos 1970. Os familiares das vítimas desse método - distinto em tudo do que podiam reconhecer como um proselitismo religioso - se organizaram para recuperar seus filhos. A noção de lavagem cerebral se impôs naquele momento como tentativa para compreender o inexplicável: a estranheza desta adesão supostamente voluntária ao moonismo. O uso da força sobre os jovens era uma hipótese quase natural para esse fenômeno que escapava às formas de apreensão habituais dos comportamentos juvenis. O que se apresentava como paradoxal era alguém escolher livremente abandonar o seu próprio universo cultural em prol de outro que possuiria uma incompatibilidade evidente com o seu. Uma técnica específica e mal conhecida de submissão das pessoas, vinda do exterior, poderia tornar compreensível a entrada de um familiar neste "outro mundo", em descontinuidade com aquele a que pertenciam os jovens pela formação, pela cultura e pelos seus valores, na perspectiva das famílias (cf. Birman 2000a:29-43). A hipótese da lavagem cerebral propiciava também que se recorresse ao Estado para combater os grupos que, longe de uma perspectiva religiosa, usavam da força para destruir as famílias.

O que se apresenta, grosso modo, no debate - que se constituiu naquela época e se prolongou até o final dos anos 1990 - é a defesa por parte deste meio associativo de uma incompatibilidade radical entre os "mundos" das seitas e da sociedade francesa, vistos como dois conjuntos dotados cada um deles de coerência própria, como totalidades excludentes entre si. A postula- 
ção de uma descontinuidade quase absoluta entre estas totalidades pôde fazer-se por intermédio de uma certa forma de conceber a pessoa e as relações identitárias. Constituiu-se neste movimento a percepção de uma continuidade natural e substantiva entre os indivíduos, suas famílias e a nação. Por intermédio desta consubstancialidade entre pessoa, família e nação, o movimento de defesa das famílias contra as seitas argumentou vigorosamente diante do Estado e da sociedade que a entrada de seus filhos nas seitas era, simultaneamente, uma violação da integridade pessoal destes e das suas famílias, bem como uma perda da soberania nacional. A indissociabilidade postulada entre estes três planos identitários permitiu a estas famílias transformar uma causa, inicialmente "local" e "doméstica", em um problema relativo às fronteiras nacionais e, assim, clamar por providências do Estado diante da gravidade e universalidade do problema sectário ${ }^{1}$. Permitiu também, posteriormente, ao longo dos anos 1990, que as associações das famílias se transformassem no "braço" moral mais importante e vigilante da sociedade junto ao Estado para detectar e denunciar a presença das seitas e seus malfeitos no território nacional.

Escolhemos compreender a emergência desse movimento social como parte de conflitos identitários e políticos envolvendo famílias e suas relações com o Estado em lugar de interrogá-lo privilegiando fundamentalmente as questões relativas ao campo religioso na sociedade francesa. Partimos da premissa, que tentaremos validar ao longo da nossa exposição, de que dificilmente os eventos político-religiosos associados a estas narrativas sobre o perigo das seitas poderão ser compreendidos se nos limitarmos às discussões acerca dos conflitos e diferenças entre igrejas e seitas e/ou os limites variáveis da secularização e da laicidade francesas. Ao privilegiar a associação entre família, homogeneidade cultural e integridade da nação, de um lado, e irracionalidade e seitas estrangeiras, de outro, os movimentos contra as seitas na França construíram o perigo das seitas como uma ameaça aos fundamentos da nação, sob a guarda da instituição familiar ${ }^{2}$. Os integrantes desse movimento sempre afirmaram com convicção que não consideram as seitas uma "religião". E, talvez, por levarem a sério esta perspectiva, argumentam que as seitas fazem o que é próprio delas fazer, isto é, retiram os indivíduos do mundo e os transformam em párias sociais. A construção deste lugar para o adepto se associou, no entanto, do ponto de vista político, a uma perspectiva nacionalista, isto é, a um certo momento da sociedade francesa em que o pertencimento a uma seita foi encarado como uma ameaça à integridade nacional ${ }^{3}$. Diferentes das religiões reconhecidas, as seitas não se adaptavam ao espaço nacional nem eram integradas à sociedade e aliadas do Estado, como as igrejas reconhecidas passaram a ser — bem ao contrário, 
constituíram-se como uma ameaça à soberania deste último. Certos segmentos da sociedade e do Estado exigiram deste um maior empenho em criar fronteiras poderosas, tanto familiares quanto individuais, contra os atrativos oferecidos em termos amplos pela globalização do religioso que ameaçariam a integridade dos indivíduos e também da nação ${ }^{4}$.

O ponto de vista da Associação, elaborado ao longo dos anos 1980, inicialmente envolveu algumas famílias de tradição católica da Bretanha, alguns poucos intelectuais parisienses de tradição laica e republicana e, também, ao menos um ex-combatente da guerra da Argélia, ideólogo da Guerra Fria. Coube a este ex-combatente, membro do serviço de inteligência, a formulação desta noção de lavagem cerebral na sociedade francesa. Segundo Alain Woodrow (apud Birman 2000a:29):

A tese fundamental desenvolvida pelo autor, é a de que os países democráticos estão à mercê de um "agressor" que procura a submissão "total e ativa" da nação a conquistar, através da "violação psíquica" cujos procedimentos de condicionamento ele descreve.

A diversidade política e ideológica dos grupos que se formaram para combater as seitas (nem todos adotaram, evidentemente, esta retórica envelhecida da Guerra Fria) não impediu a construção de orientações comuns relativas a políticas identitárias no plano local e nacional que tinham o aniquilamento da pessoa pelas seitas como premissa compartilhada.

\section{Testemunhos de estranhamento: quando um filho não volta à casa}

Nos contatos que fiz nesse meio associativo (1998 e 1999) encontrei algumas pessoas cuja militância, desde os anos 1980, orientava-se para apoiar as famílias cujos parentes tinham entrado em uma seita. A reconstituição da história familiar destas perdas (tanto próprias quanto dos outros) se fazia por narrativas cujos pontos fundamentais guardam uma semelhança com os testemunhos que estavam na origem do movimento que em Rennes, nos anos 1970, adquiriu um certo valor modelar. A proximidade reconhecida e valorizada dessas experiências se associa tanto ao ponto de vista que se estruturou como próprio deste coletivo em relação à vida familiar quanto à convicção partilhada sobre a natureza dos fenômenos sectários e a necessidade de combatê-los ${ }^{5}$.

As razões e circunstâncias que levaram um grupo de pais a se associar para defender suas famílias estão registradas na entrevista de uma das fundadoras do movimento, no primeiro número do seu boletim, em 19836. O rela- 
to destes tempos heróicos iniciais enfatiza o sofrimento das famílias diante do súbito desaparecimento de um dos seus próximos e a profunda incompreensão e perplexidade a respeito do que estaria ocorrendo com eles. Destaca o caráter novo e o aspecto inusitado da situação que os familiares destes desaparecidos tiveram de enfrentar. Foi em 1974 que um pai de família e sua esposa, ele médico generalista e ela professora universitária de alemão, habitantes de Rennes, sofreram o primeiro impacto da ação da seita Moon sobre suas relações familiares, com a adesão brusca e inusitada de um de seus filhos:

Em uma noite de outubro de 1974, um de nossos filhos não voltou para casa, em Chantepie, próximo a Rennes. Ele tinha dezoito anos, tinha recebido o seu diploma secundário em julho e estava inscrito na Universidade, no primeiro ano de Línguas Estrangeiras (Russo-Inglês). Foi sua própria escolha. Nem a nós, nem a seus irmãos, nem a seus amigos, ele falou qualquer coisa... Sua motocicleta não estava na garagem. A polícia, os hospitais não sabiam de nada. Um buraco negro... Na quinta à noite, um telefonema: nosso filho nos diz que se encontra em Lyon. Ele deixa escapar quatro letras: AUCM, mas se recusa a nos fornecer o seu endereço, tampouco contar-nos o que faz ali, nada ("Aux origines de nos associations", Bulles, 33, 1992).

Depois de procurar se informar e de tentar inutilmente convencer seu filho a retornar à casa, o Sr. e a Sra.Champolion perceberam que sequer poderiam contar com a ajuda do Estado, que de certa forma era responsável pela profunda impotência a que os pais estavam reduzidos. Com efeito, este acabara de promulgar uma lei que diminuía a maioridade para dezoito anos. Criou-se assim um impedimento legal à autoridade dos pais sobre os filhos entre dezoito e vinte e um anos, quando era uma evidência para estes o quanto seus filhos não dispunham da maturidade necessária para usufruirem desta autonomia:

A lei era impotente e então eles pediram conselho a um advogado de amigos seus. "Fundem uma associação" [...] Se este caso atingir poucas pessoas, haverá algumas reações. Mas se, ao contrário, for algo de importante, vocês irão receber muitos chamados. E, neste caso, se farão ouvir pelo público e pelas autoridades ("Aux origines de nos Associations", Bulles, 33, 1992).

Assim, para surpresa deles, muitos pais responderam à denúncia que fizeram.

A maior parte das chamadas veio de famílias de adeptos de Moon, muitas concerniam a outras seitas: Gouru Mharadj, Krishna e outras. Mas a história era 
sempre a mesma: desaparecimento súbito ou partida rápida, impossibilidade de discutir, certeza absoluta mesmo se o conteúdo fosse vago e, em todo caso, um tanto insólito. Nos primeiros dias, as chamadas e cartas chegavam da Bretanha e do Oeste, depois de toda a França e mesmo da Itália, da Bélgica, do Líbano [...] A imprensa nacional parisiense fez ecoar os artigos de Joseph Fontaine ("Aux origines de nos Associations", Bulles, 33:6-7, 1992).

As queixas, portanto, eram relativas ao abandono da família, e os parentes, assim organizados, se negaram a considerar o que um olhar exterior sobre seus problemas sugeria tratar-se de uma simples dificuldade deles em aceitarem as escolhas religiosas de seus filhos. O problema dizia respeito à ruptura com o universo familiar, inimaginável, aliás, como comportamento religioso não somente pelo conteúdo da suposta crença, mas também e, principalmente, pela violência que esta teria envolvido.

A ignorância total a respeito do fenômeno sectário, que os pais repetidamente afirmavam, exigiu, então, da parte destas famílias, a elaboração de um saber a partir de suas próprias experiências e a organização de um coletivo de ajuda mútua. Para superarem o estranhamento que estes novos eventos tinham provocado em suas vidas foram fundamentais as tentativas de reconstituição do processo de envolvimento do filho com a seita. O caráter brutal e repentino da conversão e a incomunicabilidade que se estabeleceu em seguida se transformaram em um traço destacado do comportamento codificado das seitas, reconhecido coletivamente pelos pais e repetido através de um certo modelo de narrativa que veio se fixar. $O$ relato da fundadora da $A D$ FI se transformou em uma espécie de mito de origem da associação.

Relatos feitos na primeira pessoa por familiares de jovens adeptos ocuparam um lugar de destaque e de divulgação no grupo e ajudaram a elaborar um ponto de vista comum para este ator coletivo na sociedade. No Bulles, boletim da associação, alguns depoimentos ganharam também um valor de referência, como este que citei, associado ao seu momento inaugural. É deste lugar pois que emergem as narrativas que produzem o sentido da conversão ao mundo das seitas e as transformações que estas produziram no indivíduo, visto sob a ótica da intimidade familiar ${ }^{7}$.

De certo modo, constituiu-se um modelo de descrição destes desencontros e reencontros entre familiares, em que se ressaltam os momentos de um antes e um depois. As transformações do indivíduo, depois da entrada na seita, dizem respeito aos efeitos visíveis da reclusão deste no ambiente sectário. Um relevo particular foi atribuído à aparência do adepto referida minuciosamente por alguns traços negativos: emagrecimento, desgaste corporal evidente, falta de cuidados pessoais e, principalmente, referências 
a índices de pertubação psíquica, como olhar vazio, ausência de interação, dispersão, entre outros. As famílias foram conclamadas a suspeitarem de mudanças de hábitos entre os seus: sugeria-se que estas usassem o saber acumulado na intimidade para identificarem a ação nefasta das seitas sobre os seus parentes. Descreveu-se assim, repetidamente, na forma de sintomas que participam do discurso ordinário da psiquiatria, o sentido negativo que emana do núcleo central do sujeito, situado no seu interior e supostamente vazio daquilo que lhe garantiria o seu pertencimento à família, visível principalmente na incoerência do seu comportamento no interior da esfera doméstica. Em suma, as famílias poderiam vir a público e apresentar um conjunto de sintomas de alguns de seus parentes como exemplo insofismável de uma dessubjetivação destes ocorrida no interior de uma seita.

\section{A lavagem cerebral e seus sintomas}

Os indícios que assinalam a despossessão da pessoa de si mesma são variados. Entretanto, para alguns, este processo assumiu um formato diretamente vinculado ao instrumento que o produzia. Certas referências se faziam por meio da associação da despossessão aos efeitos provocados por este instrumento, a lavagem cerebral, inventado na Guerra Fria. Os adeptos das seitas neste caso eram indivíduos que trariam marcas evidentes, no plano físico e psíquico, de terem sofrido uma despossessão por meio desse método particular. Assim, os males psíquicos adquiriam um formato preciso que anunciava, pelo que comunicavam corporalmente aos parentes, os efeitos nocivos desta modalidade de engendrar submissão. Eram gestos cuja descrição enfatizava uma incomunicabilidade que lhes seria intrínseca pelo estranhamento que produzia nos seus familiares.

Os testemunhos das famílias oferecem, pois, os signos de reconhecimento da destruição dos seus pelas seitas elaborados no interior da vida familiar, os quais revelam o quanto o comportamento do adepto é anômalo em relação à educação que recebeu e ao modo de vida que sempre compartilhou. O diagnóstico de lavagem cerebral, portanto, dizia respeito sobretudo às relações entre o adepto e sua família. O estado do primeiro impediria a existência de um campo intersubjetivo de trocas no interior desta última. Proximidade sem intersubjetividade sintetizaria, assim, o que seria o sofrimento coletivo provocado pela lavagem cerebral. Objetivar os sintomas seria também uma forma de testemunhar a incomunicabilidade e suas causas, a lavagem cerebral: 
[...] Tudo nele mudou, ele já não é mais a mesma pessoa. A expressão do rosto está congelada, seus olhos têm uma expressão estranha. Ele repete palavras como um disco, não aceita nenhuma discussão e rejeita tudo o que antigamente fazia parte de sua vida: família, trabalho [...]Em resumo, para a famíla toda a comunicação tornou-se subitamente impossível (Bulles, 0, 1983).

O mesmo estilo narrativo se encontra no testemunho de uma antiga militante, na época presidente da ADFI, ao descrever a transformação do seu marido e da vida familiar:

Eu comecei a falar com ele e lhe perguntei: "O seu guru é músico?" Bastou que eu pronunciasse o nome dele (do guru) e pronto, flop, a fita gravada começou a rodar e, em seguida, o delírio: "a música ... não, eu não toco este gênero de instrumento ..." Eu não sei mais o que ele me contou, era uma outra pessoa falando. Era aquilo que a seita tinha posto na sua cabeça. Se eu atingisse um pouco o seu território mais íntimo, aquele que a seita não tinha usurpado, ele continuava a ser a pessoa com a qual se podia dialogar. Mas, se você dissesse uma palavra: "O senhor Amsa Manara", flop, flop [...] Meu marido estava falando normalmente e aí, pronto, a fita gravada recomeçava a tocar.

A imagem de um robô surge assim, espontaneamente, como a forma mais adequada de designar esta experiência. Com efeito, nesses relatos, falta aos gestos e à linguagem a flexibilidade complexa e variada que os seres vivos apresentam na medida em que são sujeitos do que enunciam. E é a falta do poder de enunciação manifestada pelo adepto que faz da experiência com este um testemunho da sua subordinação, por meio da lavagem cerebral, ao grupo que a realizou. A imagem da fita cassete condensa o essencial desse fenômeno: a exterioridade, em relação ao indivíduo, do comando de suas ações é entrevista nesse diálogo impossível pela falta suposta de um dos pólos da troca intersubjetiva, substituído pelos dizeres da seita, cujo formato seria para alguns o equivalente de uma glossolalia, indicando claramente quem é o agente deste espaço subjetivo "esvaziado"8:

Há toda uma técnica para a lavagem cerebral. Há todo um mecanismo, quer dizer, quando se entra numa seita, a gente entra numa armadilha. No início, a gente diz a si mesmo que está indo porque este grupo vai responder às nossas questões. Logo no começo, se acredita nele. E depois, ao mesmo tempo em que existe esta manipulação, há também a mudança na alimentação, a falta de sono. Fisicamente, a gente se encontra num estado algo letárgico. A gente tem o cérebro um pouco anestesiado [...] estão incrustando em você uma espé- 
cie de fita cassete que responde a todas as questões e que faz de você um adepto integral, com toda esta linguagem dentro da cabeça ${ }^{9}$.

Trata-se, pois, da descrição de alguém despossuído de agência e cuja relação e comunicação com os outros é impossível por meio da linguagem incompreensível da seita, exterior a sua pessoa tanto na forma quanto no conteúdo. Os membros sectários dessas famílias se transformaram em imagens aterrorizantes deste encontro improvável entre dois mundos estranhos e antagônicos entre si, cuja distância foi superada da única maneira disponível, qual seja, pela sujeição completa de um ao outro ou, em outros termos, pela negação de um pelo outro através do uso deste bizarro instrumento de guerra, a lavagem cerebral, e o seu antídoto, a desprogramação. Na entrada dramática para uma seita, ao mesmo tempo em que a família perderia um dos seus, o adepto perderia a sua capacidade de existir no mundo, como a sua fala desconectada de si bem indicaria.

O estado físico e psíquico sugerido pelo comportamento linguístico e psicológico "robotizado" constituiu-se como um padrão descritivo constantemente posto em relevo e divulgado para as inúmeras famílias que recorriam aos serviços das associações contra as seitas. A descrição deste estado enfatiza a presença desta outra linguagem que indica a perda de agência do sujeito:

Como médico, um sujeito realmente perfeito, muito calmo, com muita pose, falando do seu ofício (que é uma vocação), falando de seus pacientes, de seu ritmo de vida no hospital ... realmente um cara muito humano, com quem se tem vontade de conversar. Tão legal que depois eu lhe disse: "é interessante conversar com você, mas você está lá, no sítio do Mandaron. Você é adepto deles". E, de repente, você vê o indivíduo dizendo: "sim, o senhor Amsar Manara, ele caça os lemurianos, ele evitou a Terceira Guerra Mundial". E eu nesta hora me perguntava: "como um ser humano tão inteligente pode ter esta dupla linguagem simultaneamente? É realmente inacreditável ${ }^{10 ! "}$

A elaboração de uma lista de sintomas e de conselhos às famílias atingidas se transformou em um recurso pedagógico divulgado pela ADFI e posteriormente encampado por outras associações e também pelo Estado, no final dos anos 1990. Um dos primeiros documentos desse tipo, informado de modo implícito pela noção de lavagem cerebral, buscava orientar o comportamento dos pais para uma reaproximação com seus filhos:

Alguns conselhos para os próximos

Se você puder manter o contato com a pessoa amada que entrou numa seita, 
eis alguns conselhos caso ela esteja na seita, mas também para o caso de sua saída da seita.

Não ataque o seu guru, sua crença, sua nova filosofia. Quando se fala a um adepto sobre suas crenças, você ativa nele um reflexo devido ao seu condicionamento e ele vai vender a você o discurso da seita como se estivesse ligado a um gravador [...] (Bulles, 50:10, 1996) ${ }^{11}$.

Sugere-se assim às famílias que não contrariem o adepto e que se apóiem em possíveis traços da sua memória afetiva e intelectual, aqueles que talvez permitam "puxá-lo" de volta ao mundo, aumentando uma possível "zona" de contato, não atingida inteiramente pela ação do guru sobre ele.

Uma outra militante dessa associação me contou comovida que, por ignorar estas regras, perdeu para sempre sua filha para uma seita. Ela aceitou ir a um programa de televisão para denunciar o guru, o que engendrou um rompimento definitivo da filha, que lhe nega, ainda hoje, muitos anos passados, qualquer contato com seus netos.

Certos traços encontrados nos jovens reafirmavam, nos relatos privilegiados pela ADFI, o que teria sido um ataque injustificado e profundamente pertubador dos jovens à herança social e moral de seus pais. Comportamentos anômicos, em antagonismo evidente com o que lhes foi transmitido, se somam facilmente ao rol dos sintomas valorizados pelos parentes. O capitaine Morin, ideólogo da lavagem cerebral e participante ativo deste movimento, destaca: eram famílias de médicos, professores, advogados, empresários que se queixavam da lavagem cerebral feita a seus filhos e, mais raramente, a um dos cônjuges ${ }^{12}$ :

Senhor J.F.M., pai de uma vítima: "Meu filho, excelente estudante de uma Grande Escola, se demitiu para entrar numa organização diabólica [...]"

Senhor S., Dordogne: "Meu filho único, Jean Pierre, com 31 anos, entrou na faculdade de Medicina de Bordeaux em 1964 [...]"

M. M. Pai de uma vítima: "Minha filha, Marie Christine, estudante brilhante do terceiro ano de medicina $[\ldots]$ "

Madame S. "Minha filha Evelyne, 22 anos [...] Meu marido, industrial... ele quis conhecer o destino de sua filha e pediu para acompanhar uma doutrinação da qual não pôde mais sair. Contrariando sua vontade consciente, ele se encontra profundamente engajado neste movimento, ao qual cedeu todos os lucros de sua usina [...]" (Morin 1976:34-35).

O abandono da casa paterna significou assim, em inúmeros casos, o desmantelamento de uma ordem familiar, ou simplesmente a recusa inimaginável de um dos membros da família à vida que lhe era oferecida: próspera e bem 
estruturada, cujo horizonte apontava para uma ainda maior acumulação de riqueza e prestígio. Indícios como estes, citados por Morin, aumentavam o valor da hipótese da lavagem cerebral, na medida em que destacavam o contraste entre as ofertas da família e as fornecidas pelas seitas. O abandono de uma vida prestigiosa e um futuro garantido, em relevo na narrativa de alguns pais, forneceram a Morin um argumento para fazer da violência sobre o adepto o único meio para se compreender a irracionalidade inexplicável desta súbita conversão às seitas de pessoas como estas. O desprezo do adepto pela distância incomensurável e natural entre os dois mundos e também a negação da superioridade social e cultural do primeiro em relação ao segundo só seriam superados pelo uso da desprogramação. Era, pois, verossímel compreender a irracionalidade destes comportamentos como efeito de um mecanismo físico e psíquico capaz de construir indivíduos-objeto, em ruptura evidente com o meio social de origem ${ }^{13}$. Em Je porte plainte, de 1981, Roger Ikor lista as práticas zen-macrobióticas que deixam claro para o leitor a distância incomensurável que separa a seita de seu filho — uma "comunidade" religiosa alternativa - dos valores básicos da civilização ${ }^{14}$. A lavagem cerebral tal como teria sido praticada na Guerra Fria é o eixo que articula os dados arrolados pelo testemunho paterno.

Posteriormente abandonada nas narrativas que dominaram a cena pública nos anos 1990, ou melhor, progressivamente eufemizada, a categoria lavagem cerebral foi de uso corrente neste meio durante pelo menos uma década, quando a noção de manipulação ganhou a frente e se transformou no ano 2000, inclusive, em categoria de uso genérico com valor jurídico ${ }^{15}$. A passagem de um sentido literal para outro mais metafórico, ou, para uma maior alternância entre um e outro, se fez mais claramente e de forma quase definitiva a partir do momento em que o Estado passou a condenar e penalizar a prática do seu antídoto, a desprogramação.

\section{A linguagem das seitas contra a linguagem das famílias}

Durante muito tempo, as minhas tentativas de entrevistar pessoas ligadas às associações aqui mencionadas esbarravam em um obstáculo que se revelou rapidamente como um mal-entendido. Cada vez que buscava encontrar uma vítima das seitas recebia como sugestão buscar suas famílias ${ }^{16}$. Pareceu-me depois de algum tempo que jamais poderia encontrar aqueles que seriam as "verdadeiras" vítimas destas conversões. O que estava em jogo, pensei posteriormente, além das tentativas eventuais de controle político das narrativas sobre a destrutividade das seitas, era propriamente a condição de vítima que 
parecia complexa e que de certo modo estava posta em questão. Nada mais natural, por um lado, que as famílias falassem por aqueles que teriam perdido a condição de se defenderem (Boltanski 1993). Este movimento de falar pelo outro desvalido lhes era reconhecido como legítimo não somente porque a condição de parentes lhes daria uma legitimidade maior para ocuparem este lugar de tutela, mas também pela necessidade que reivindicavam de reconhecimento político da destruição em curso, o que exigia testemunhos, mesmo que por pessoa interposta. No entanto, o estado de destruição em que o parente se encontrava se transformou rapidamente em matéria controversa, e a dúvida sobre a natureza da lavagem cerebral sofrida criava uma zona de sombra onde vítimas e algozes se confundiam. Os parentes tinham de lidar com a desconfiança pública a respeito de suas próprias intenções. Seriam estas, meras reações aos ventos liberadores que atingiam os valores familiares que defendiam? Será que os adeptos não deveriam ser considerados responsáveis pelas escolhas que faziam? Os adeptos das seitas eram também objeto de desconfiança das próprias famílias: afinal, como robôs obedientes aos seus gurus, não seriam co-partícipes, apesar deles mesmos, das tentativas de desestruturação das famílias?

A condição de vítima do adepto trazia embutida, em suma, a idéia de que este podia ser também algoz da própria família e quiçá da sociedade. Do ponto de vista destas famílias, defender a presença da lavagem cerebral significava sobretudo defender a própria família como instituição e como expressão de um certo ethos, ameaçado pela conversão de um de seus membros. Nestas circunstâncias, as famílias seriam sempre vítimas: pela perda de um dos seus e pela perda da sua integridade como instituição.

A dificuldade resultava então da minha ignorância sobre a distância social que me separava das evidências partilhadas nesse meio associativo. A aderência do indivíduo à família fazia da sua coerência um atributo do coletivo familiar, e a experiência de estranhamento da família, um efeito produzido pela perda no adepto de sua subjetividade no interior da seita. Em alguns casos, por exemplo, mesmo quando se reconhecia que os filhos estavam perfeitamente integrados ao "meio sectário" - e não pareciam infelizes - aventava-se uma desintegração social e pessoal que eles estariam sofrendo e que se somava à destruição da unidade familiar. Os parentes enunciavam também com ardor que tinham sido privados de seus descendentes e, em conseqüência, da continuidade social e afetiva que teriam por intermédio dos filhos. Viram-se impedidos, também, pelo efeito da mecânica das seitas e do descaso do Estado, de guardar no interior das famílias um campo de relações intersubjetivas com os filhos - em alguns casos, até um simples contato lhes teria sido interditado. 
As narrativas familiares repetem insistentemente o fato de os filhos terem deixado de ouvir, isto é, de terem se retirado da esfera de assentimento mútuo que domina o ambiente familiar modelar, e que também falavam uma linguagem que seria incompreensível provinda da seita, a qual invadia o espaço familiar e o colocava em perigo. A incomunicabilidade no interior das famílias teria como causa maior a capacidade específica de dominação do guru e também a pouca habilidade das famílias, como vemos, de contornar os mecanismos vigentes de submissão. Em um dos quadros de informações da ADFI nessa época, me deparei com uma frase, escrita com letras enormes, que clamava: "Gurus, libertem nossos filhos!".

O guru, chefe da seita, se transformou, assim, em um tipo ideal cujo perfil correspondia ao de antagonista por excelência das famílias. Seria aquele que dispõe do poder de produzir seres robotizados porque, como é inteiramente estranho à ordem famíliar e seus valores, é incapaz de produzir pessoas. Impõe-se pelo engano e pelo uso de mecanismos cujos efeitos apagam, ao menos temporariamente, as conexões entre o adepto e o seu meio social de origem. O que o guru transmite é o oposto de tudo que é engendrado pela família: enquanto esta cria vínculos, forma e integra seus membros no conjunto social maior, o guru desconecta as pessoas e dissolve seus vínculos com o mundo. O contraste entre os pais e os gurus ressalta a importância dos primeiros para a sociedade (e o dever do Estado em garanti-la) e define a ação imposta pelos últimos como mecânica, desprovida de afeto e desconectada do mundo social que possibilita o florescimento das pessoas. Este mesmo contraste pôde ser operado no campo político como um antagonismo que fez das famílias os atores por excelência do combate às seitas assumido pelo Estado, durante os anos 1990.

A eficácia do mecanismo da lavagem cerebral coloca em antagonismo dois modos de relacionamento: um natural, conduzido pela linguagem do afeto e pela hierarquia familiar, e outro proveniente de uma linguagem artificial que se impõe pela força e dispensa a adesão e o consentimento livre, criando pessoas "robotizadas". Deste ponto de vista, a palavra das vítimas será a dos membros da família que têm acesso à linguagem natural, cujas experiências subjetivas podem servir como testemunhos de sofrimento em um espaço de relações sociais correntes, onde a comunicação é possível.

A desprogramação foi, então, um modo de ação que nos anos 1970 e 1980 se colocou no âmbito desses grupos associativos como alternativa para superar a distância entre mundos incompatíveis: seria a ponte, a passagem e o instrumento capaz de abrir uma brecha para dar lugar a um fluxo mais permanente e também dialógico no futuro. A identidade substancial da pessoa foi, como se disse, violada, por meio da lavagem cerebral que fechou, 
por sua vez, seu psiquismo a investidas do exterior. A vítima deveria, em conseqüência, ser submetida a um tratamento que anulasse os seus efeitos, capaz de restituir a sua condição de sujeito, a posse plena de sua identidade e o reencontro com sua família.

A coragem necessária e em parte questionável para praticar o rapto de seus próprios filhos maiores foi referida nos primeiros números de Bulles, que não deixou de advertir os seus leitores sobre o perigo de transgredir as leis do país. A ADFI foi buscar, nos Estados Unidos, informações sobre a lavagem cerebral e os procedimentos de desprogramação em curso no outro lado do Atlântico ${ }^{17}$. A desprogramação foi percebida pela fundadora da ADFI como uma técnica cujo valor maior residiria no fato de "abrir caminho" para um reencontro familiar efetivo. Fazê-la era uma decisão difícil, cuja eficácia, no entanto, já estaria comprovada por psiquiatras americanos e as associações contra as seitas daquele país. A atitude de pais americanos foi apresentada como fonte de exemplo da dedicação à família, a ser seguido no seu país:

Muitas famílias tinham "salvo" seus filhos, às vezes, por intermédio de um verdadeiro rapto, mais freqüentemente, graças a uma decisão da justiça lhes concedendo a guarda por um certo tempo. Em todo caso, eles (os filhos) tinham sido obrigados a ouvir o "conselheiro" (exit counsellor) e os testemunhos, as informações sobre as organizações e os tráficos da sua seita e dos chefes. Alguns dos "liberados" presentes atestaram que suas famílias jamais lhes teriam dado maior prova de amor [...] riscos graves, despesas significativas e, em caso de fracasso, a prisão talvez [...].

Estes pais estavam prontos a se desdobrar para ajudar os outros pais. Impossível resumir as discussões tão densas que tivemos a este respeito. Mas, disso tudo, me restou a convicção de que não existe "des-programação" mecânica. Há um longo processo que tem como força motriz o amor recíproco entre os membros de uma família, entre amigos, ajudados por outros que conhecem bem o problema. Estamos tão longe da "lavagem cerebral" quanto da pressão do grupo e da chantagem afetiva (Bulles, 4, 1984).

O reencontro entre pais e filhos é, assim, o final feliz e encorajador deste drama, resolvido pela família com o auxílio do desprogramador. O testemunho de uma jovem "desprogramada" publicado em Bulles permite compreender o imaginário familiar que se encontra envolvido nestas propostas e o incentivo à sua prática:

Eu percebia que mentia. Pouco a pouco, eu comecei a falar, ou melhor, a pregar as doutrinas de Hare Krishna. Mas, a cada vez, os "desprogamadores" refutavam 
meus argumentos e eu me fechava de novo em mim mesma, cantando em voz alta. Eu gostaria de deixar claro que durante este dia eu só comi o que eu quis. O momento mais emociontante da minha vida:

Eles me falavam do controle mental, do brain washing, da hipnose; então eu decidi estudar, eu mesma, essas informações e estas práticas para, em seguida, tomar uma posição. Eu me dizia: talvez eu esteja sob controle mental, submetida à lavagem cerebral, mas quem disse que eles não querem que eu me submeta da mesma maneira? Depois de três ou quatro horas em que eu li estudos sobre controle mental e testemunhos de pessoas de outras seitas, sentindo-me identificada demais, eu pedi ajuda aos "desprogramadores" e escutei a experiência de duas ex-moonistas que estavam lá. Foi incrível verificar que a experiência delas era semelhante à minha, a delas travestida em cristã e a minha em hindu. Houve uma conversa longa e aberta e depois eu pedi para ver meu pai. Eu o beijei, chorei e lhe agradeci, tudo ao mesmo tempo (Bulles, 4, 1984).

\section{Uma contribuição da ciência: máquinas, adeptos e o apóstolo automático}

Este indivíduo sem agência, dominado pelas seitas, ganhou um reforço em termos de sua construção pela sedução que, na época, exerciam a inteligência artificial e o ainda pouco conhecido computador e a linguagem da informática. Assim, um desdobramento desse imaginário associado aos novos potenciais da tecnologia se apresentou no campo de reflexão sobre as seitas através de tentativas de pensar lógicas locais e totalitárias de que estas seriam um exemplo. A aproximação dos discursos das famílias com o discurso científico e as novas tecnologias da informação foi fruto do sofrimento que um pesquisador enfrentou com a perda de sua família para uma seita católica. Nos anos 1970, na mesma época em que se passavam estas conversões abruptas em algumas províncias francesas, um eminente professor universitário em Paris, pertencente a uma das grandes famílias protestantes da França, foi também atingido por uma seita cujo guru, Roger Melchior, converteu sua esposa e a transformou em sua amante, partindo depois para a Bélgica com ela e seus filhos menores. A história da seita é contada por Yves Lecerf em múltiplas denúncias que faz contra ela, em que buscou envolver o meio universitário e intelectual parisiense, a igreja protestante da qual fazia parte e também o meio associativo anti-seitas ${ }^{18}$. Yves Lecerf fez uma tese sobre a seita dos irmãos Melchior, criou um laboratório voltado para estudar o fenômeno sectário, o Laboratório de Estudo das Seitas e dos Mitos do Futuro, em Paris 7, forneceu à causa dos pais, pela sua colaboração ativa com a associação destes, um discurso mais elaborado sobre a 
modalidade de despersonalização provocada pelas seitas e ampliou o movimento para outras "famílias" ideológicas.

Interessado nos mecanismos da linguagem, Lecerf, como lingüista que era, incentivou a inventividade de seus colegas de laboratório a fim de que elaborassem instrumentos analíticos e metodológicos voltados para a compreensão das linguagens artificiais em uso nas seitas e nas instituições totalitárias de uma forma geral. Foi criado um programa de computação que foi batizado de "apóstolo automático" [apôtre automatique] ${ }^{19}$. O programa tinha como finalidade, por um lado, expor de forma didática para diferentes platéias como funcionava uma máquina capaz de produzir respostas programadas por um agente do exterior, como se ela própria tivesse feito "escolhas" e, por outro, testar vocabulários em uso na seita e em outras instituições totalitárias de modo a estabelecer o caráter limitado e fechado desta linguagem codificada ${ }^{20}$. O apóstolo automático, portanto, encenava um indivíduo submetido a uma linguagem artificial e seus mecanismos operatórios - o que tornava visível, por analogia, como este era levado pelo emprego desta linguagem a responder mantendo-se no limite estreito das associações que esta permitia. A pobreza e o caráter "fechado" de certas linguagens explicariam como os seus usuários se transformavam em seres incapazes de escapar do automatismo das respostas previamente codificadas. O sucesso do apóstolo automático, segundo seu criador, se deveu em parte à época em que o encantamento com a informática estava na ordem do dia, e os limites sociais de sua aplicação eram pouco discutidos ${ }^{21}$.

O apóstolo automático freqüentou a universidade, circulou para suas variadas platéias e forneceu meios para, no âmbito dos movimentos contra as seitas, pensar a lavagem cerebral de forma mais ampla, associando seus mecanismos a procedimentos científicos e a teorias da linguagem com valor universal. O estranho poder dos gurus sobre as pessoas ganhava assim a sua positividade. Com efeito, podemos perceber que o apóstolo automático, sobretudo os seus princípios de operação, vão se incluir em quadros ideológicos diversos onde as noções de totalitarismo/instituição total aparecem como chave de leitura comum. A noção de "instituição total" se apresenta como um instrumento analítico potente e referido com insistência pelos colaboradores de Yves Lecerf no livro coletivo que publicaram sobre a seita que capturou sua mulher e filhos (Lecerf 1975).

Segundo um dos membros desse laboratório, na época, havia um projeto político e ideológico que orientava parcialmente a construção do apóstolo automático: a denúncia do crescimento das seitas, em curso na sociedade francesa, não poderia ser dissociada do que se passava no plano internacional e nas muitas instituições totalitárias, associadas ao desenvolvimento capitalista em 
escala mundial. Este esforço de denúncia visava igualmente romper com a indiferença do meio acadêmico, cuja neutralidade ideológica deveria ser posta em questão em relação aos vínculos que esta teria com a reprodução de indivíduos demasiadamente obedientes, capazes de aderir a enormes bobagens sem a mínima reflexão e espírito crítico, nas próprias instituições francesas:

A gente se pôs a construir um programa: fizemos um "maoísta", um "testemunha de Jeová". Um "Menino de Deus" que tinha saído da seita nos ajudava a elaborar o programa, ele contribuiu para melhorá-lo. Nossa posição moral e política não era a mesma que aquela dos sociólogos — nós éramos ferozes; como não éramos reconhecidos, fazíamos processos de intenção [...] Recusávamos a neutralidade: como se fosse possível estudar a ascensão do nazismo na Alemanha sem tomar partido... A construção de um protocolo de intenções seria semelhante. Recusávamos isto. Jaulin tomava partido dos índios ${ }^{22}$.

Havia a preocupação entre alguns membros do laboratório de colaborarem com a ADFI, ajudando-a a apresentar suas bandeiras contra as seitas de forma a não ser definida como "de direita" e voltada unicamente para a proteção da família. Seria possível e desejável insistir, a partir de uma perspectiva mais universalista, sobre os efeitos físico-psíquicos da conversão sectária ${ }^{23}$. A aproximação entre as vítimas da "direita" (guerra do Vietnã, nazismo, imperialismos) e as vítimas da "esquerda", provenientes dos regimes comunistas, se deu por intermédio da noção de "lavagem cerebral", que teve seu campo de aplicação estendido às vítimas de todos os sistemas, de forma a poder cobrir um vasto espectro ideológico. O apóstolo automático, exemplo da linguagem artificial das seitas, revelava o que se passava em todo e qualquer militante, um ser incapaz de colocar em dúvida as mentiras provenientes da China maoísta bem como do seu partido político, ou da igreja que freqüentava: depois que entrava no círculo estreito da sua linguagem, não duvidava mais dos "gurus" e obedecia "cegamente" a seus mandamentos. O fanatismo, uma figura conhecida da irracionalidade, é associado a mecanismos de dominação que ferem simultaneamente o indivíduo - que perde sua autonomia e o seu livre-arbítrio — - a família e a nação, corroídos pela intransigência e determinação cega desta forma específica de adesão e de pertencimento social. O fanatismo, figura universal, passível de definição científica, seria de certa forma estranho à cultura nacional: tanto na forma quanto no conteúdo se distanciava dos valores comuns da nação e dava lugar à destruição promovida por certas potências estrangeiras, ligadas a cartéis internacionais (Lecerf 1975; Ikor 1981).

Romper a artificialidade imposta aos adeptos para fazê-los recuperar a linguagem natural e contribuir para a defesa da sociedade nacional se transformou 
em um projeto político cuja diversidade ideológica não impedia o desenvolvimento de um programa de ação comum. Com efeito, a linguagem natural e também a linguagem nacional e da civilização garantiriam a comunicação entre as pessoas e seriam, também, indicadores da racionalidade que as preside. A razão como um dos atributos universais da humanidade, reivindicada como um dos fundamentos da cultura republicana, ganhou, nestas circunstâncias, um vínculo estreito com certos valores morais tradicionais, ameaçados pelas seitas ${ }^{26}$.

\section{O "Affaire" Château}

Em março de 1982, Claire Château, jovem moonista, foi puxada para dentro de um carro em movimento, em uma rua central da cidade onde distribuía prospectos da sua seita. Gritou por socorro para os transeuntes, que nada puderam fazer além de anotar a placa do carro e testemunhar, posteriormente, à polícia. A investigação policial comprovou o que alguns já suspeitavam: entre os seqüestradores constavam os seus pais e membros da ADFI. Para o embaraço de todos, a jovem, submetida a um exame psiquiátrico, mostrou-se em perfeita posse da sua capacidade mental:

Reencontradas, na sexta-feira à noite, pelos investigadores do SRPJ de Dijon, em uma casa próxima a Saint Claude (Jura), as sete pessoas foram entregues ao Tribunal de Justiça de Besançon [...] A inculpação de "seqüestro", prevista pelo artigo 341 do código penal, foi decidida depois que um exame médico-psicológico mostrou que a Srta. Château gozava de perfeita saúde mental (Le Monde, 9/03/1982).

Após esta tentativa fracassada de desprogramação, a jovem contrariou os seus pais novamente e voltou para a seita. O seu retorno foi interpretado por estes como a continuação do domínio da seita sobre ela — não tiveram tempo para agir e desfazer a lavagem cerebral. Acusavam, assim, a seita de ser a responsável pelo comportamento da filha. A seita respondeu com um processo, acusando a família e a ADFI de difamação. Estes dois atores se acusavam mutuamente com o concurso da mídia. Aparentemente, só havia dois atores em disputa pela posse de Claire Château, a seita e o coletivo das famílias. A jovem apareceu na imprensa através desses dois papéis possíveis e excludentes entre si: como "vítima da seita" ou, talvez, como afirmava a seita, como "vítima da sua família". Criou-se, contudo, um mal-estar generalizado na discussão deste affaire pela imprensa, diante de uma ação cujo teor desrespeitava as leis do país e os direitos da jovem em suposto estado de despossessão. Para a 
infelicidade geral, os dispositivos psiquiátricos oficiais não tinham sido capazes de identificar os sintomas da lavagem cerebral de que seria vítima. A justiça e a polícia, por mais embaraçadas que estivessem, não poderiam se eximir de aplicar a lei:

Elas (a polícia e a justiça) existem para fazer com que a lei seja respeitada. Esta última diz cabalmente: o rapto e o seqüestro por mais de dois dias são imputáveis de uma pena de dois a cinco anos de reclusão. Mas não será um escândalo levar o Sr. e a Sra. Château a julgamento? (Le Monde, 9/03/1982).

O Le Monde, na mesma reportagem, apresenta o ponto de vista "dos jovens" que seriam essencialmente favoráveis ao direito à liberdade de Claire Château, em oposição à opinião da geração de seus pais:

De forma geral, os jovens são mais pela filha: 'é preciso respeitar nossa liberdade, ainda que seja para fazer uma bobagem', enquanto as pessoas mais idosas defendem o ponto de vista dos pais, com os quais facilmente identificam-se (Le Monde, 9/03/1982).

O "conflito de gerações" foi, no entanto, pouco explorado pela imprensa. A defesa dos direitos de Claire Château saiu rápido de cena para dar lugar à grande batalha dos defensores das famílias contra os ataques da seita, na imprensa. Ainda assim, o fato de o Estado francês, mesmo apresentando o seu imenso constrangimento, ter posto os pais de Claire Château na prisão foi vivido pelo meio associativo como uma afronta à dignidade dos militantes e um ataque às suas famílias. As manifestações das famílias foram, de modo geral, apoiadas pela imprensa: os pais se sentiam com este affaire "insultados, injuriados, alienados dos direitos mais sagrados para nós, sobre nossas famílias". Parecia-lhes que, para o Estado francês, "os chefes de família que somos são pessoas suspeitas a seus olhos", em uma inversão escandalosa da ordem social - punem-se os cidadãos e liberam-se os malfeitores (Birman 2000a:35).

Não se chegou a aventar verdadeiramente a possibilidade de considerar Claire Château, uma interlocutora legítima neste debate em que era apresentada como vítima pelas duas instituições em disputa. A linguagem das seitas através da qual ela poderia se comunicar não teria lugar, de fato, no espaço público. Somente a Igreja Católica produziu uma interpretação em que reconhecia a linguagem de Claire como religiosa e, portanto, plena de sentido ${ }^{25}$.

Apesar da desconsideração pela sua palavra, a defesa e a reparação devidas a ela pelo Estado tornou pública, e de certa forma evidente, a necessidade de considerar as demandas dos pais como relativas. A fratura pública 
exibida pelo seqüestro de Claire Château tornou não somente mais visível a heterogeneidade do corpo familiar, negada em grande medida por este movimento associativo, como também o que seria a conseqüência deste fenômeno: que a heterogeneidade da família pela maior individualização de seus membros poderia engendrar interesses contraditórios que o Estado teria por obrigação considerar. A fragmentação da família teatralizada e midiatizada pelo seqüestro fez emergir identidades em conflito que recolocaram em outros termos o tratamento a ser dado à questão das seitas, particularmente a ambigüidade do Estado em relação às "desprogramações" em curso. Apesar do caráter inapropriado das escolhas de Claire Château, sob todos os pontos de vista - o que atestava a sua profunda irracionalidade - , a questão da tutela dos filhos maiores, reivindicada pelas famílias, colocava um problema. Afinal, esse movimento associativo estava indo na contramão das transformações sociais alcançadas no pós-68, todas apontando no sentido de uma maior individualização e autonomização das pessoas com relação aos elos da "tradição"26.

A proposta que surgiu do "Relatório de Alain Vivien", publicado em 1983, tinha como motivação específica responder ao conflito aberto em torno das seitas por parte das famílias ${ }^{27}$. O "Relatório" propôs, além de um efetivo investimento do Estado na vigilância e prevenção das atividades das seitas, uma solução conciliadora através da qual se poderia restaurar, ainda que de forma provisória, o poder parental sobre filhos menores de 21 anos, por intermédio de um juiz que operaria como mediador entre as partes. Esta proposta foi criticada por diferentes segmentos sociais, que apontavam como esdrúxulo o "direito" de uma família pedir a suspensão da maioridade de um de seus filhos. Em um artigo interessante, um padre jesuíta — insuspeito em relação ao valor atribuido à família — coloca a questão ${ }^{28}$ : por que um juiz deverá escutar o que os pais de um jovem adulto teriam a dizer sobre as opções de vida deste?

\section{Da lavagem cerebral à manipulação mental: horizontes políticos}

Embora esta solução não tenha tido curso, o "Relatório Vivien" (1983) ${ }^{29}$, elaborado após o traumático seqüestro de Claire Château, contribuiu para o abandono progressivo das tentativas de combate às seitas por intermédio de seqüestros e desprogramações. A lavagem cerebral que estava no centro da proposta de lei do capitaine Morin, que sugeria penas de prisão elevadas para aqueles que praticassem o "viol psychique", também foi desconsiderada ${ }^{30}$. De certo modo, o affaire Château marca também o início do fim da noção de lavagem cerebral relacionada ao perigo das seitas, substituída paulatinamente 
pela noção de manipulação mental. Esta mudança que se deu progressivamente, da lavagem cerebral para a manipulação mental, significou uma reorientação do debate sobre as seitas a partir de uma outra concepção de pessoa, mais individualizada e também menos homogênea e coerente, o que tornou mais claramente imperativo o debate sobre os limites do livre-arbítrio e os sentidos possíveis do consentimento ${ }^{31}$. No entanto, a "interiorização" de uma dominação sectária por estes indivíduos livres e liberados das raízes familiares não diminui - como vemos no "Relatório" — , o perigo social e político que decorreria destas escolhas individuais, na medida em que a ruptura do adepto com a sua família é postulada — a partir deste "Relatório" que veio orientar a ação do Estado - como um dos signos mais importantes do abandono de valores morais que se encontrariam como fundamentos da nação:

Psicologicamente, os seres humanos parecem, na realidade, alienar a sua autonomia; e o comportamento de certos adeptos conduz, algumas vezes, as autoridades médicas a suporem a dominação de uma droga que não puderam, no entanto, comprovar. A alienação moral é, certamente, tão grave quanto [...] Membros que escolhem romper com suas famílias se subtraem, às vezes, de uma vida normal em sociedade. Abandonando seus estudos, largando o aprendizado de um ofício, eles podem, além disso, romper com a sua dependência nacional porque a seita passa a ser uma supra-nacionalidade. Os adeptos aceitam moralmente o estatuto de apátrida [...] Se as associações que proclamam objetivos inteiramente religiosos ou filosóficos — seus adeptos, aliás, subsistindo com o mínimo vital - se dedicam a transferências clandestinas de divisas, o Estado, então, tem o direito de intervir com o maior rigor possível. Se o trabalho fornecido pelos cidadãos franceses se organiza inteiramente para exportar fundos consideráveis em direção a organizações estrangeiras, os poderes públicos não podem deixar de reagir (Vivien 1983:25).

Movimentos ilegais de divisas, de bens e de pessoas podem ser fruto das atividades daqueles que perderam suas referências nacionais.

O personagem sectário, configurado como um indivíduo sem agência e sem qualquer lealdade às suas raízes nacionais, será, a princípio, suspeito de favorecer os interesses de multinacionais. Os cuidados de proteção às fronteiras frente ao perigo das seitas passam a incluir, no "Relatório", a vigilância às possíveis fontes de pertencimento dos indivíduos, suspeitas de conexões com o exterior. A presença de adeptos em empresas e instituições diversas passou a ser referida correntemente como uma "infiltração" que ameaçaria os interesses nacionais durante, ao menos, todo o período em que o autor deste "Relatório", Alain Vivien, foi o responsável pelas inúmeras 
comissões de nível ministerial, encarregadas de combater o perigo sectário $^{32}$. A defesa da integridade nacional se faz assim presente no "Relatório Vivien" contra as seitas ${ }^{33}$. O movimento contra as seitas envolveu racionalistas republicanos e católicos conservadores que se fizeram igualmente presentes em todas as comissões ministeriais encarregadas, no plano do Estado, de combater este perigo para a sociedade. Chama a atenção que adversários tradicionais de outros tempos - católicos e republicanos - tenham se transformado, ao longo deste processo, em aliados para combater um inimigo nacional comum.

Posteriormente, os movimentos contra as seitas se diversificaram e ampliaram suas agendas. Cresceu também, ao longo dos anos, o número de indivíduos que reclamava, em nome próprio, do abuso de poder cometido no interior de grupos diversos, incluindo cada vez mais aqueles pertencentes às igrejas estabelecidas ${ }^{34}$. A questão da autonomia e do respeito à integridade da pessoa, como valor associado à defesa dos direitos humanos e à prática da democracia, não excluiu os grupos sectários cujos princípios de obediência religiosa seriam muitas vezes percebidos como antagônicos ao exercício destes direitos ${ }^{35}$. No entanto, os valores potencialmente diversificados a partir dos quais se defende a noção de autonomia parecem guardar uma tensão não resolvida com certos princípios de identificação nacional, em constante reafirmação. O antagonismo suposto e freqüentemente reafirmado por segmentos do Estado, entre linguagens vindas do exterior e a linguagem social ordinária, parece se sustentar em uma convicção relativamente disseminada na sociedade de que a heteroglossia, sobretudo aquela proveniente de fontes religiosas externas, pode, digamos, se transformar em uma glossolalia, e assim trazer um risco difícil de ser acolhido pela sociedade. A noção de religião nestes embates ganhou um contorno mais claramente nacional, em oposição à noção de seita, cuja distância dos valores morais dominantes se associou a uma perda desta "substância identitária" comum que ligaria cada indivíduo à nação.

Recebido em $1^{\circ}$ de junho de 2004

Aprovado em 25 de fevereiro de 2005

Patricia Birman é professora de Antropologia da Universidade do Estado do Rio de Janeiro. E-mail: <patriciabirman@terra.com.br> 


\section{Notas}

${ }^{1}$ Boltanski (1990) faz uma análise interessante sobre a construção de passagens entre a esfera privada e a esfera pública elaboradas por indivíduos e movimentos para alcançar legitimidade e visibilidade na esfera pública: que meios são utilizados pelos indivíduos para serem ouvidos nesta esfera?

${ }^{2}$ As primeiras elaborações dessa pesquisa se encontram no texto que apresentei como parte do concurso para professor titular em Antropologia na UERJ (cf. Birman 2000a). Agradeço os comentários que, na época, fizeram Peter Fry, Pierre Sanchis, Regina Novaes, Cecília Mariz e Gilberto Velho, os quais me permitiram continuar a trabalhar algumas pistas abertas neste texto. Pude, nos anos subseqüentes, de 2001 a 2003, explorar melhor o meu material, como também ampliar o meu trabalho de campo, por meio de entrevistas e análise dos arquivos dessas associações. Sem dúvida, a ampliação da minha rede de relações pessoais e acadêmicas na França foi fundamental para dar seqüência a esta pesquisa. Expus o esboço deste artigo no Seminário do CRBC/EHESS, coordenado por Afrânio Garcia e Marion Aubrée, aos quais agradeço pelas críticas e comentários. Gostaria de agradecer igualmente o convite dos colegas Patrice Roland, coordenador do Grupo de Trabalho sobre a questão das seitas do Laboratório GRSL/IRESCO, e o seu coordenador, Jean-Paul Willaime, que me propiciaram uma rica discussão deste trabalho.

${ }^{3}$ Cf. Helly 2001 e Schnapper 2001 para análise histórica da noção de comunidade e de comunitarismo na França e na Europa. Também o artigo de Stolke (1995), que analisa o crescimento, nos anos 1970, do que ela designa como uma nova retórica de exclusão na Europa que sublinha a diferença de identidade cultural como um grave problema social e político.

${ }^{4}$ Este movimento, ao propor uma descontinuidade radical entre "seita" e "religião", busca efetivamente excluir da noção de religioso certas práticas em desacordo com princípios morais que teriam um valor nacional. Para uma análise da mutação dos critérios de definição do religioso acerca da questão das seitas e a forma de conceber esta relação na França, ver Champion e Cohen 1998 e para uma análise do emprego da noção de seita, suas controvérsias políticas e as posições assumidas pelo movimento anti-seitas e pelas igrejas, ver Blanchard 1998; Birman 1999, 2000a; Giumbelli 2002 e Hérvieu-Leger 2001; para uma descrição etnográfica do movimento anti-seitas, suas associações e também as suas controvérsias políticas, ver Giumbelli 2002; para uma análise das controvérsias jurídicas e análises de processos judiciários ver Durvet 1999; para uma análise da identidade católica da 
nação francesa, ver Lambert 1985 e Hérvieu-Leger 1999; para uma discussão em termos mais amplos sobre a historicidade da noção de religião e suas relações com a construção dos Estados-nação, ver Asad 1999.

${ }^{5}$ As sete pessoas que entrevistei nesse período tinham o cuidado de se aterem à versão "oficial" de suas associações sobre o sentido das experiências das famílias com as seitas. Elas oscilavam no emprego dos termos "lavagem cerebral" e "manipulação mental". A entrevista com a presidente da ADFI é a que apresenta mais claramente o uso da noção de lavagem cerebral, tal como enunciada nas publicações da associação. Ao menos duas entre as pessoas entrevistadas escreveram livros que enfatizam os testemunhos de familiares, incluindo aqueles relativos às suas famílias: Tavernier 2003; Delporte e ADFI-Nord 1998.

${ }^{6}$ Cf. Bulles. Bulletin de Liaison pour l'Etude des Sectes, publicado pela l'UNADFI a partir de 1983.

${ }^{7}$ Em 1981 foi fundada outra associação contra as seitas, CCMM (Centre Roger Ikor), cujo apelo e divulgação estiveram fortemente vinculados ao livro voltado para a denúncia das seitas do seu fundador, Roger Ikor, que testemunhou sobre o acompanhamento da experiência do seu filho em uma seita e acusou o Estado pela falta de providências. Denunciou ainda a irresponsabilidade social da lei que abaixa a maioridade penal no país. O seu livro virou referência para familiares em busca de orientação em todo o país (cf. Birman 2000a). Tive acesso aos arquivos da CCMN e da ADFI (nesta última, de forma mais controlada e parcial) relativos à correspondência mantida por estas associações com as famílias: é impressionante não somente o volume de cartas de familiares pedindo orientação para compreenderem o comportamento estranho de seus próximos, como também o fato de buscarem encontrar nos seus familiares os sintomas de pertencimento sectário sugeridos pelas associações (cf. Birman 2000a e 2000b). Giumbelli (2002), na sua descrição desses movimentos associativos, nos fornece um conjunto interessante de dados estatísticos sobre a correspondência das famílias nestas duas principais associações.

${ }^{8}$ Thomas Robbins (1986) descreveu este comportamento "robótico" de norteamericanos atingidos por seitas como um modo de encenação caricatural dos adeptos das seitas que visaria comprovar o fato de que eles teriam sido doutrinados por uma certa tecnologia: "Tenho ouvido narrativas sinistras de adeptos de seitas que estão falando com seus parentes ou terapeutas e, repentinamente, mudam a totalidade de seus padrões vocais e passam a falar-arengar-grunir em vozes alienígenas e, posteriormente, não guardam nenhuma lembrança do episódio" (1986:14). O fenômeno apontado por Robbins pode ser melhor entendido, a meu ver, através da noção de 
glossolalia. Segundo a sugestiva interpretação de Agamben (2003:125): "O falar línguas" que está em questão na epístola (de Paulo aos Coríntios) designa um fenômeno lingüístico - a glossolalia — no qual o falante fala sem saber o que diz ('ninguém o compreende, e é em espírito que ele diz seus mistérios', I Cor.14,2). Ora, isso significa que o próprio princípio da fala torna-se, aqui, algo de estrangeiro, de 'bárbaro' - isto é, segundo o próprio sentido do termo barbaros, um ser privado de logos, um estrangeiro que nem escuta, nem fala verdadeiramente. A glossolalia expõe, então, a aporia de uma absoluta dessubjetivação e 'barbarização' de um fenômeno lingüístico, no qual o sujeito falante cede lugar a um outro, criança, anjo, bárbaro, que fala 'no ar' e de maneira 'estéril'".

${ }_{9}^{9}$ Depoimento da mesma presidente da ADFI.

${ }^{10}$ Continuação do mesmo depoimento.

${ }^{11}$ Estes conselhos foram publicados no primeiro número do boletim e posteriormente republicados com algumas modificações.

12 É interessante a apresentação que Morin faz de si mesmo em seu livro. Ele destaca que viveu na Algéria durante os "acontecimentos" da guerra colonial e posteriormente veio para a América Latina, onde se "apaixonou" pelo estudo da subversão. Diplomou-se em criminologia e, para combater a proliferação de seitas "político-religiosas", criou uma disciplina visando estudar o fenômeno recente da violação psíquica no quadro da subversão (designada de "psicopolemologia", pelo próprio autor).

13 James Beckford (1979), em um texto precursor, analisou os movimentos anti-seitas como uma forma de restabelecer as fronteiras entre o que seria ou não aceitável em termos da natureza da pessoa e da sociedade.

14 Destaca, assim, as práticas ligadas a um grupo de zen-macrobiótica: jejum, vida comunitária, vegetarianismo, acompanhados de um certo isolacionismo e recusa de integração na vida social corrente - este conjunto de elementos, aparentemente anódino, é descrito como parte de um plano deliberado de engendrar um enfraquecimento físico que redundaria no domínio psíquico da seita sobre o indivíduo. Aproxima, implicitamente, os campos de concentração do nazismo e do estalinismo dessas práticas de destruição sistemática dos indivíduos. Segundo Ikor, este enfraquecimento levou seu filho ao suicídio (Cf. Birman 2000a). Para uma análise destes movimentos apelidados de "neo-ruraux", ver Hervieu-Léger, D. e Hervieu, B. (1979), onde os autores descrevem (sem muita simpatia) o que seria um certo "vazio" existencial dos jovens "comunitários". 
${ }^{15}$ Cf. o artigo de Patrice Roland 2003, sobre o debate legislativo a respeito da lei sobre a manipulação mental. Não pretendo desenvolver no âmbito deste artigo o sentido desta passagem da lavagem cerebral para a manipulação mental. Pode-se dizer que esta passagem diz respeito a uma maior individualização da vítima e interiorização dos motivos de sua adesão ao meio sectário, fenômeno que complexificou o debate a respeito da exterioridade total ou não do sujeito a estes métodos de dominação. As versões mais "duras" da lavagem cerebral, hoje francamente minoritárias, convivem com esta noção de manipulação mental, o que possibilita inúmeras passagens entre elas. Sherril Mulhern (1996) defende que uma versão soft da lavagem cerebral, a desestabilização mental, estaria dando o eixo das manifestações contra as seitas, como verificou no relatório que a Assembléia Legislativa francesa elaborou no ano de 1995. A análise de Hervieu-Léger (2001) sobre a desestabilização mental reitera, a meu ver, o ponto de vista desenvolvido por Mulhern. Para uma análise destas categorias na sociedade americana ver Bromley, D. e Richardson, T. 1983.

${ }^{16}$ De preferência aquelas que participavam das associações [...] Esta mesma percepção se manteve no período seguinte do meu trabalho de campo (de 2001 até 2003), quando consegui manter relações mais amigáveis e distendidas com algumas pessoas desse meio associativo. O nexo entre família e vítima orienta de forma relevante, neste período, a definição daqueles que são considerados vítimas das seitas.

${ }^{17}$ A fundadora da ADFI foi visitar os grupos anti-seitas americanos para obter informações sobre os métodos de desprogramação daqueles que eram vítimas da lavagem cerebral. A associação também traduziu e publicou artigos científicos sobre o tema de psiquiatras americanos reconhecidos, como John Clarck e Margareth Singer, defensores deste método. Publicou também testemunhos favoráveis à desprogramação de ex-adeptos e de seus familiares.

${ }^{18}$ Devo a valorização dos elos entre a ADFI e este setor da universidade francesa a uma excelente conversa que tive com a antropóloga Sherril Mulhern, antiga colaboradora de Lecerf e membro desse laboratório. A partir de 2001, conversei (em níveis variáveis de formalidade) com quatro outros antigos membros desse laboratório. Lecerf, além de ter conseguido uma imensa presença na imprensa da época (mais de cem reportagens foram feitas denunciando a seita, segundo ele mesmo), editou um livro contra a seita de sua ex-esposa, no qual incluiu artigos de intelectuais franceses reconhecidos, como Michel de Certeau e Robert Jaulin, de personalidades do meio protestante e católico e de colegas do seu próprio laboratório. Os fundadores da seita terminaram condenados por abuso de menor na Bélgica (onde se instalaram), depois de um percurso pontilhado por acusações de escroquerie e charlatanismo. Sua ex-esposa também foi condenada por cumplicidade com estes malfeitores. 
${ }^{19}$ Lecerf apresenta em um artigo publicado em Archives des Sciences Sociales de la Religion (Lecerf 1980) este programa de computação, defendendo a utilização dos instrumentos informáticos como meio de avançar na compreensão do fenômeno sectário. Diz ele: "Nós queremos evocar, aqui, os trabalhos conduzidos no Laboratório de Etnologia de Seitas da Universidade Paris VII [...] que colocam em jogo: por um lado, objetos informáticos imperfeitos que são os programas de diálogo automático, por intermédio dos quais um computador sustenta conversas em linguagem natural com quaisquer pessoas, simulando um condicionamento religioso sectário, ou mesmo um condicionamento ideológico (Testemunha de Jeová automático, Menino de Deus automático, Maoísta automático etc)". Este artigo de Lecerf se produziu no quadro de uma mesa-redonda organizada por Emile Poulat, no Congresso Bianual da Association Française de Cybérnetique Economique et Technique sobre o tema "Petits Groupes et Grands Systèmes", em novembro de 1979. Em um artigo introdutório, onde apresenta o resumo dos trabalhos dessa mesa, Poulat chama atenção para a necessidade de se investigar o elo "religioso e cibernético": "[...] eu fiquei espantado em perceber que o religioso - vago, impreciso ou metafísico - aparecia, aí, como o recalcado do discurso científico" (Poulat 1980:131-132). De modo geral, a tese de Lecerf sobre as seitas parece ter sido ignorada pelo meio acadêmico.

${ }^{20}$ Segundo Lecerf (1980:140-141), os instrumentos fornecidos pela informática permitiriam maior avanço no estudo da linguagem das seitas, do que os instrumentos disponíveis para a etnologia: "É importante perceber que a noção de linguagem própria a uma seita é uma noção precisamente identificável, podendo mesmo tornar-se objeto de descrições generativas relativamente exatas, se lhe dermos a atenção necessária. Os sistemas categoriais utilizados pela etnologia das religiões para definir a noção de seita não possuem, até agora, as mesmas qualidades e rigor lógico; a tal ponto que não podemos afirmar que existam verdadeiramente, até o presente, definições reais desses objetos etnológicos que chamamos usualmente de seitas. A noção de linguagem específica para uma seita fornece, ao contrário, uma definição indireta e parcial, certamente, mas precisa".

${ }^{21}$ Entrevista com um antigo membro do laboratório.

${ }^{22}$ Cf. o artigo de Robert Jaulin no livro organizado por Yves Lecerf (1975) onde a crítica da seita se apresenta como uma denúncia generalizada e radical das sociedades ocidentais e suas formas de dominação, associando como vítimas por meio deste argumento, tanto os índios da Amazônia quanto os adeptos da seita dos irmãos Melchior.

${ }^{23}$ Com efeito, a valorização da "linguagem natural" em oposição à artificialidade daquela que engendra indivíduos sectários se inscreve em um debate em que as 
fronteiras entre diferentes correntes de pensamento parecem se dissolver. A oposição aos movimentos "neo-rurais" e hippies, que surgiram nos anos 1970, podia incluir facilmente as correntes racionalistas republicanas e também os católicos tradicionais por razões distintas: as primeiras, pelo desprezo aos vínculos sentimentais que pareciam soldar as "comunidades" contra a soberania do Estado republicano, e os segundos, pelo flagrante menosprezo que os jovens comunitários demonstravam em relação aos valores morais e cristãos ligados ao trabalho, à responsabilidade individual e à sexualidade. Sobre a universalização da condição de vítima e sua autonomização de uma coloração ideológica, ver a análise de Boltanski 1993, sobretudo o ilustrativo debate que descreve entre Sartre e Merleau-Ponty a respeito da denúncia dos casos das vítimas dos gulags.

${ }^{24}$ Jean Baubérot, ao discutir certas transformações históricas da moralidade laica, aponta o "desenraizamento" desta como parte de um processo de modernização e individualização em curso na sociedade: "A República precisa de um ser humano moral e livre, quer dizer, capaz de auto-vigiar-se; de interiorizar as regras para poder vivê-las desenraizado de suas obediências tradicionais e do olhar dos outros: de forma geral, passamos de uma sociedade de vigilância a uma sociedade de controle." (Baubérot 2000:63). No entanto, nesse momento a que nos referimos, se reestabeleceu um projeto de base racionalista que via o "enraizamento" dos indivíduos na família uma possível forma de defesa do indivíduo e da nação.

${ }^{25}$ Em uma entrevista ao principal jornal católico da França, Claire Château denuncia os métodos empregados pelos desprogramadores e se declara profundamente católica e religiosa. Justifica a sua entrada na seita pelo seu desejo de unificar todas as religiões, incluindo o budismo. Afirma: "Eu já estava em busca de tudo que concernia à religião. Dentro da Igreja Católica, mas também no budismo e nas religiões orientais. E eu tinha o desejo de unificar todas as crenças" (La Croix, 24/3/1982).

${ }^{26}$ A referência política que acompanhava estas disputas no plano público era dada pela insatisfação de certos segmentos sociais com as mudanças relativas à família no código civil. Elas estavam reclamando também — por intermédio do seqüestro - de um processo acelerado de mudanças atingindo as disposições jurídicas que garantiam os poderes tradicionais da família: as modificações do código civil que se encadearam a partir de 1967/1968 atingiram o estatuto que estas possuíam na sociedade — no novo código se estabeleceu o direito à contracepção, em dezembro de 1967; o reconhecimento obrigatório dos filhos naturais como filhos legítimos, em 1972; o direito ao divórcio sem culpa estabelecida de uma das partes, em 1974; o direito ao aborto, em 1974; a maioridade aos 18 anos, em 1974. Este conjunto de leis indica que a instituição familiar já estava profundamente posta em questão e que o movimento contra as seitas nesta época pode ser considerado 
como uma reação conservadora a estas transformações em curso. Agradeço a Martine Cohen por estes dados relativos às transformações da família. Cf. Singly 1993.

${ }^{27}$ Este Relatório foi o resultado de uma demanda do Ministère des Affaires Sociales et de la Solidarité Nationale, chargé de la Famille, em 1982.

${ }^{28}$ A Igreja Católica oficialmente considerou que a autonomia dos jovens frente às famílias não os impediria de voltarem, em um outro momento, à igreja que os tinha formado. De forma geral a voz oficial da Igreja não acompanhou as posições do movimento contra as seitas. Considerava que mais valia defender a legitimidade de movimentos místicos, ainda que desenvolvidos por outros grupos, do que defender a parte do seu rebanho que se sentia ameaçada pelas seitas (cf. Introvigne 1996, que defende o ponto de vista do Pontificado a este respeito). Ao longo dos anos 1990, no entanto, a pressão do Estado e da mídia forçou um recuo da Igreja, cujo representante oficial passou também a denunciar, embora sempre de forma mais moderada, os malefícios das seitas Cf. Blanchard 1998; Hérvieu-Léger 2001 e Giumbelli 2002, sobre a participação da Igreja Católica nas controvérsias sobre as seitas.

${ }^{29}$ Les Sectes en France. Expressions de la liberté morale ou facteurs de manipulations? Rapport au Premier Ministre. La Documentation Française, 1983.

30 Morin propõe que o viol psychique seja considerado um crime, a ser punido com prisão entre 10 e 20 anos (cf. Giumbelli 2002:83). Na análise que faz do "Rapport Vivien", Giumbelli considera que "o projeto da associação mediadora do 'juiz de família' e da tutela provisória marcará a especificidade do 'Relatório Vivien'. Ele é ao mesmo tempo uma 'resposta às famílias', uma arma contra os grupos, uma garantia para os indivíduos e uma demonstração da capacidade de intervenção do Estado". Na minha opinião, o Estado francês aumenta o seu controle porque o seu papel de defensor da soberania nacional, foi percebido pelas seitas como estando sob ameaça, naquele momento. O que será o Estado francês senão aquele Estado-nação que, no Ocidente moderno, melhor conseguiu se impor como a encarnação dos ideais nacionais e da própria nação?

${ }^{31}$ Para uma discussão da noção de pessoa relacionada à perda do livre-arbítrio nas seitas ver Beckford 1979.

${ }^{32}$ Este tema foi exaustivamente desenvolvido no Relatório da Assembléia Nacional, Les sectes et l'Argent, de Jacques Guyard e Jean-Pierre Brard, em junho de 1999. A questão da infiltração do Estado pelas seitas se constituiu como um tema recorrente na imprensa, alimentado pelas sucessivas denúncias das múltiplas 
Missões Interministeriais de Luta contra as Seitas, coordenadas pelo mesmo Alain Vivien, durante o governo socialista, entre 1996 e 2002. Destas missões, também participaram, além de figuras públicas, grupos associativos diversos, o Capitaine Morin e representantes da ADFI e do CCMM. Estas duas associações, uma falando em nome das famílias e a outra em nome da razão e da república, mantiveramse ao longo dos anos como as principais referências relativas ao combate às seitas. Operaram como o braço direito do Estado nas suas intervenções de controle e de vigilância em todo o território nacional. Baubérot (1990), analisando a história da laicidade francesa, demonstra como o antagonismo entre os valores das famílias e os valores republicanos se manifestava no passado. Longe da afinidade que se vê, hoje, este autor fornece exemplos interessantes deste antagonismo: como se faziam ataques republicanos às mães de família, vistas como aliadas da igreja e contrárias aos valores da razão e da república.

${ }^{33}$ O Boletim do CCMM (associação fundada por Roger Ikor que também foi presidida pelo responsável pelo Relatório que citamos, o "Rapport Vivien") se constituiu a partir da década de 1990 como um virulento veículo de denúncia das infiltrações sectárias em instituições diversas.

${ }^{34} \mathrm{O}$ interesse pelo problema das seitas aumentou na sociedade e ganhou uma maior legitimidade a partir dos massacres provocados pela OTS (Ordem do Templo Solar) na Suíça e na França, no final de 1995, o que colocou diretamente a questão da responsabilidade do Estado em defesa dos cidadãos em relação a estes grupos (ver nota 4 para referências).

${ }^{35}$ Neste sentido, teriam contribuído para aumentar o processo de secularização da sociedade francesa, como apontam diferentes autores. Para testemunhos sobre maltratos no interior da Igreja Católica, ver Baffoy, Delestre e Sauzet 1996. 


\section{Referências bibliográficas}

AGAMBEN, Giorgio. 2003. Ce qui reste d'Auschwitz. Paris: Rivages Poche. ASAD, Talal. 1999. "Religion, NationState, secularism". In: Van der Veer and Hartmut Lehmann (eds.). Nation and religion. Perspectives in Europe and Asia. Princeton: Princeton University Press.

BAFFOY, Thierry; DELESTRE, Antoine e SAUZET, Jean-Paul. 1996. Les naufragés de l'esprit. Des sectes dans l'Eglise Catholique. Paris: Seuil.

BAUBÉROT, Jean. 2000. Histoire de la laïcité française. Paris: PUF. (Collection Que sais-je?)

__. 1990. Vers un nouveau pacte laïque? Paris: Le Seuil.

BECKFORD, James. 1979. "Politics and anti-cults movements". Annual Review of the Social Sciences of Religion, 3:169-189.

BLANCHARD, Arnaud. 1998. Le religieux controversé, la constitution $\mathrm{du}$ "problème des sectes" comme problème public. Mémoire de troisième cycle, École Normale Supérieure de Cachan.

BIRMAN, Patricia. 1999. “Entre França e Brasil: viagens antropológicas em um campo (religioso) minado". Horizontes Antropológicos, 10:13-34. . 2000a. Religiosidade, pluralismo e nação: as seitas na França hoje. Tese apresentada para o concurso público de Professor Titular de Antropologia no Departamento de Ciências Sociais da Uerj, março de 2000. Mimeo.
_ . 2000b. "Multiculturalité religieuse en France: vers un nouvel Orient?". Ethnologie Française, 4: 565-574.

BOLTANSKI, Luc. 1990. L'amour et la justice comme compétences. Paris: Métaillé.

___ 1993. La souffrance à distance. Morale humanitaire, médias et politique. Paris: Métaillé.

BROMLEY, David e Richardson, James T. (eds.). 1983. The brainwashing/ deprogramming controversy: sociological, psychological, legal and historical perspectives. New York: Edwin Mellen.

CHAMPION, Françoise e COHEN, Martine. 1999. Sectes et démocratie. Paris: Editions du Seuil.

DELPORTE, Charline e ADFI-Nord. 1998. Témoins de Jéhovah: les victimes parlent. Paris: Editions Arthème Fayard.

DUVERT, Cyrille. 1999. Sectes et Droit. Thèse de doctorat, Université Panthéon-Assas (Paris II).

FOURNIER,Anne e Picard, Cathérine. 2002. Sectes, démocratie et mondialisation. Paris: Puf.

GIUMBELLI, Emerson. 2002. O fim da religião. Dilemas da liberdade religiosa no Brasil e na França. São Paulo: Attar.

HELLY, Denise. 2001. "Communauté et citoyenneté". Anthropologie et Societé, 25(3):11-29.

HÉRVIEU-LÉGER, Danièle. 1999. Le pèlerin et le converti. La religion en 
mouvement. Paris: Flammarion. 2001. La religion en miettes ou la question des sectes. Paris: Calmann-Lévy.

IKOR, Roger. 1981. Je porte plainte. Paris: Albin Michel.

INTROVIGNE, Maximo. 1996. Pour en finir avec les sectes. Le débat sur le rapport de la commission parlementaire. Paris: Editions Dervy.

LAMBERT, Yves. 1985. Dieu change en Bretagne. Paris: Cerf.

LECERF, Yves. 1980. "Des techniques de simulation de dialogues sur ordinateur comme auxiliaires de la recherche ethnologique en matière de sectes". Archives de Sciences Sociales des Religions, 50(1):140-141. . 1975. Les marchands de DIEU. Analyse socio-politique de L'Affaire Melchior. Bruxeles: Editions Complexe.

LÉGER, Danièle e Hérvieu, Bertrand. 1979. Le retour à la nature. Au fond de la forêt...l'Etat. Paris: Seuil.

MORIN, Jean-Pierre. 1976. Le viol psychique. La psychopolemologie: un nouveau procede de subversion. Paris: Éditions R. Garry.

MULHERN, Sherril. 1996. "Du 'lavage du cerveau' à la 'désestabilisation mentale'". In: M. Introvigne e G. Melton (eds). Pour en finir avec les sectes. Le débat sur le rapport de la commission parlementaire. Paris: Éditions Dervy. pp. 99-103. POULAT, Emile. 1980. "Un système transnational de 1'Eglise Catholique". Archives de Sciences Sociales des Religions, 50(1):131-132.
ROLAND, Patrice. 2003. "La loi du 12 juin 2001 contre les mouvements sectaires portant atteinte aux droits de l'homme. Anatomie d'un débat législatif". Archives de Sciences Sociales des Religions, 121:149-165.

ROBBINS, Thomas. 1986. "Goodbye to Little Red Ridinghood". Update. A quaterly Journal on New Religious Movements, 10(2):5-18.

SCHNAPPER, Dominique. 1991. La France de l'intégration. Sociologie de la Nation en 1990. Paris: Editions Gallimard.

STOLKE, Verena. 1995. "Talking culture: new bounderies, new rhetorics of exclusion in Europe". Current Anthropology, 36:1-24.

SINGLY, François. 1993. Sociologie de la famille contemporaine. Paris: Nathan Université.

TAVERNIER, Janine. 2003. 20 ans de lutte contre les sectes. Paris: Editions Michel Lafon.

THOMAS, Joseph. s.j. 1985. "Le rapport Vivien sur les sectes". Etudes, 362366(6): 773-776.

VIVIEN, Alain. 1983. Les sectes en France. Expressions de la liberté morale ou facteurs de manipulations? Rapport au Premier Ministre. Paris: La Documentation Française.

. 2003. Les Sectes. Paris: Odile Jacob.

WOODROW, Alain. 1977. Les nouvelles sectes. Paris: Editions du Seuil. 


\section{Resumo}

Este artigo analisa a constituição dos movimentos contra as seitas na sociedade francesa, direcionada à defesa de valores familiares, nos anos 1980. Busca destacar de que forma estes movimentos conseguiram se impor no espaço público e fazer da questão das seitas um problema relativo à integridade da nação e de seus membros. A associação entre família, homogeneidade cultural e integridade da nação, de um lado, e irracionalidade e seitas estrangeiras, de outro, fez do perigo das seitas uma ameaça aos supostos fundamentos da nação, sob a guarda da instituição familiar.

Palavras-chave Seitas, Família, Religião, Ciência, Nação

\section{Abstract}

This paper examines the upsurge of anti-sect movements in France during the 1970s and 80s, and their accompanying defence of family values. It explores the ways in which these movements gained public attention and influence, as well as their success in transforming the issue of sects and beliefs into a problem of national and family unity. The distinct associations made between family, cultural homogeneity and national unity on one hand, and between irrational and foreign sects on the other, has transformed the perceived danger posed by the sects into a threat to the very foundations of the nation and its dependence on the family institution.

Key words Sects, Family, Religion, Science, Nation 